\title{
PENINGKATAN MUTU MADRASAH BERKELANJUTAN (SUSTAINABILITY) BERBASIS KINERJA GURU
}

\author{
Suhirman \\ Dosen Jurusan Tadris IPA Biologi IAIN Mataram
}

\begin{abstract}
Abstrak
Masih rendahnya tingkat profesionalisme guru saat ini disebabkan oleh faktor-faktor yang berasal dari internal guru itu sendiri dan faktor lainnya yang berasal dari luar. Pada konteks madrasah, beberapa sifat yang harus dimiliki guru antara lain: pendidik harus memiliki keteladanan (uswah hasanah) dalam sifat tujuan, tingkah laku da pola berpikir guru bersifat rabbani yakni hendaknya selalu bersandar kepada Rabb dengan mentaatiNya, mengabdi kepadaNya, mengikuti syariatNya dan mengenal sifat-sifatNya; hendaknya guru seorang yang ikhlas; guru bersabar dalam mnegajarkan berbagai pengetahuan kepada anak-anak; jujur dalam menyampaikan informasi; senatiasa membekali diri dengan ilmu dan kesediaan membiasakan diri untuk terus mengkajinya, guru berpengetahuan luas dengan ilmu yang dikajinya; hendaknya guru mampu menggunakan berbagai metode mengajar secara bervariasi. Penguasaan ilmu saja belum cukup, karena tidak setiap orang berilmu mampu mentrasformasikan ilmunya kepada peserta didik secara efektif; guru mampu mengelola siswa, tegas dalam bertindak serta meletakkan berbagai perkara secara proporsional; mempelajari kehidupan psikis para pelajar selaras dengan masa perkembangannya ketika mengajarkannya; tanggap terhadap berbagai kondisi dan perkembangan dunia yang mempengaruhi jiwa, keyakinan; dituntut bersikap adil terhadap seluruh siswa.
\end{abstract}

Kata kunci: Mutu, Madrasah Berkelanjutan, sustainebility, berbasis, kinerja. 


\section{PENDAHULUAN}

Pendidikan merupakan modal utama bagi suatu bangsa dalam upaya meningkatkan kualitas sumberdaya manusia yang dimilikinya. Sumberdaya manusia yang berkualitas akan mampu mengelola sumberdaya alam dan memberi layanan secara efektif dan efisien untuk meningkatkan kesejahteraan masyarakat. Oleh karena itu, hampir semua bangsa berusaha meningkatkan kualitas pendidikannya termasuk Indonesia.

Pembangunan dunia pendidikan merupakan bagian yang tidak dapat dipisahkan dari kerangka besar pembangunan nasional. Karena salah satu tujuan pendidikan nasional adalah mencerdaskan kehidpan bangsa, sebagaimana termaktub dalam pembukaan Undang-Undang Dasar 1945 alenia ke-4. Dimana mencerdaskan keidupa bangsa maknanya mencerdaskan seluruh aspek khidupan meliputi seluruh tumpah darah bangsa Indonesia agar mampu hidup layak, terhormat dan sejajar dengan bangsabangsa lain di dunia.

Sebagai konsekuensi logis dari pembangunan dunia pendidikan ini adalah munculnya kebutuhan pemerataan pendidikan bagi semua lapisan masyarakat yang secara langsung akan meningkatkan mutu sumber daya manusia (human resources) bangsa Indonesia. Keberadaan lulusan pendidikan merupakan sumber daya manusia yang akan menjadi subyek dan obyek pembangunan. Karena itu peningkatan kualitas sumber adaya manusia ini perlu terus dilakukan peningkatan seiring dengan perkembangan dan kemajuan ilmu pengetahuan dan teknologi.

Menurut Fasli Jalal dan Dedi Supriyadi (2001), keberhasilan pembangunan dibidang pendidikan bukan saja dapat diketahui dari mutu secara individu warga negara, namun juga erat kaitanya dengan mutu kehidupan masyarakat, berbangsa dan bernegara. Dengan demikian dunia pendidikan tidak saja bertangung jawab terhadap dirinya sendiri melainkan juga memiliki tangung jawab yang sangat besar dalam menentukan arah keberhasilan tujuan pembanagunan bangsa.

158 BIOTA: Jurnal Tadris IPA Biologi FITK IAIN Mataram 
Untuk meningkatkan kualitas pendidikandiperlukan suatu proses yang integral semua sumber daya pendidikan, termasuk peningkatan sumber daya manusia. Pemerintah dan kalangan swasta secara bersama-sama telah dan terus berupaya melaksanakan peningkatan tersebut melalui berbagai usaha pembangunan pendidikan yang lebih berkualitas, diantaranya dengan pengembangan dan perbaikan kurikulum, sistem evaluasi, perbaikan sarana pendidikan, pengembangan dan pengadaan bahan ajar, peningkatan profesionalisme guru dan tenaga kependidikan lainnya serta membuat regulasi yang mendukung terciptanya iklim kondusif bagi praktek pendidikan nasional.

Upaya yang dilakukan pemerintah dalam meningkatkan kualitas pendidikan bagi Bangsa Indonesia adalah diterbitkannya Undang-Undang (UU) Nomor 20 Tahun 2003 sebagai penyempurnaan dari Undang-Undang Nomor 20 tahun 1989 tentang Sistem Pendidikan Nasional. Pada Pasal 3 undang-undang tersebut menjelaskan bahwa Pendidikan Nasional berfungsi mengembangkan kemampuan dan membentuk watak serta peradaban bangsa yang bermartabat dalam rangka mencerdaskan kehidupan bangsa, bertujuan untuk berkembangnya potensi peserta didik agar menjadi manusia yang beriman dan bertakwa kepada Tuhan Yang Maha Esa, berakhlak mulia, sehat, berilmu, cakap, kreatif, mandiri, dan menjadi warganegara yang demokratis serta bertanggung jawab.

Mutu pendidikan ditentukan oleh berbagai factor, salah satu diantaranya adalah guru. Oleh karena itu, perlu untuk meningkatkan mutu keprofesionalan guru. Upaya meningkatkan mutu guru telah banyak dilakukan baik oleh pemerintah maupun pihak swasta antara lain seperti penyetaraan guru dan pelatihan dalam berbagai bidang atau aspek yang berhubungan dengan penguasaan dan pendalaman materi ajar, strategi dan metode pembelajaran, tekhnik penilaian hasil belajar siswa. Namun, pelatihan-pelatihan tersebut tidak berkelanjutan (sustainability). Oleh karena diperlukan satu terobosan agar pelatihan dapat memberikan dampak terhadap pengembangan keprofesian berkelanjutan. Pelatihan harus menyentuh langsung pada 
pemecahan permasalahan yang dihadapi dalam kinerja guru sehari-hari.

Kalifikasi akademik dan sertifikasi profesi guru yang harus menjadi perhatian serius dari pemerintah maupun pemerintah daerah, akan tetapi perlu juga dipikirkan pembinaan dan pengembangan profesi dan karier guru yang meliputi pembinaan dan pengembangan kompetensi pedagogik, kompetensi kepribadian, kompetensi social dan kompetensi professional. Hal ini diamanatkan dalam pasal 32 Undang-Undan Nomor 14 Tahun 2005 tentang Guru dan Dosen, sedangkan pasal 34 undangundang tersebut mengamanatkan bahwa pemerintah dan pemerintah daerah wajib membina dan mengembangkan kualifikasi akademik dan kompetensi guru pada satuan pendidikan yang diselenggarakan oleh pemerintah, pemerintah daerah dan atau masyarakat.

Pembinaan dan pengembangan profesi dan karier guru ini perlu dilakukan secara kontinyu, sehingga terdapat keberlanjutan para guru dalam mengembangkan proses pembelajaran yang berlangsung dikelas dan dalam masyarakat. Sehingga guru terpacu dan termotivasi untuk senantiasa melaksanakan profesinya secara maksimal. Untuk ini, mengingat ranah pengembangan keprofesian yang cukup luas, perlu dipilih suatu model pembinaan dan pengembangan keprofesian dan berbasis kinerja guru yang dapat dilakukan oleh para guru sendiri dengan tidak meninggalkan tugasnya.

Permasalahan dunia pendidikan di Indonesia menurut Suyanto dan MS. Abas (2001) adalah mutu atau kualitas pendidikan. Kualitas pendidikan ini menyangkut pada setiap jenjang pendidikan. Khususnya jenjang pendidikan dasar dan menengah. Sebenarnya upaya-upaya yang mengarah pada peningkatan mutu pendidikan telah lama dilakukan oleh pemerintah, diantaranya adalah pencanangan peningkatan kualitas pendidikan dengan menetapkan empat kebijakan strategis, yakni pemerataan kesempatan, peningkatan relevansi, mutu dan efisiensi pendidikan. Melalui upaya-upaya tersebut pemerintah sangat berharap agar kualitas pendidikan di Indonesia segera mengalami peningkatan secara signifikan.

160 BIOTA: Jurnal Tadris IPA Biologi FITK IAIN Mataram 
Dalam salah satu edisinya The Jakarta Post (Volt. 19 Nomor 127: 2001) mengungkapkan bahwa sistem pendidikan di Indonesia adalah terburuk di Asia dengan skor 6,21 di bawah Vietnam yang memiliki skor 6,56. Sebelumnya majalah Asian Week (1999) memuat sebuah laporan yang menyatakan bahwa terpuruknya mutu pendidikan tinggi di Indonesia dibandingkan dengan negara-negara di Asia, Australia dan Selaindia Baru.Banyak faktor yang menyebabkan mengapa terjadi rendahnya mutu pendidikan diantaranya adalah faktor distorsi yang sering terjadi di dunia pendidikan, yang pada akhirnya gejala inilah yang menimbulkan berbagai dampak yang kurang baik dalam pengelolaan dan peningkatan mutu pendidikannya.

Adapun faktor-faktor distorsi yang dimaksud adalah sumberdaya manusia yang ada dalam sekolah atau madrasah tersebut, yang meliputi kepala sekolah/madrasah, guru, siswa. Pertama adalah kepala sekolah atau madrasah adalah pemimpin pendidikan yang bertugas dan bertangung jawab mengembangkan mutu sekolah/madrasah. Kedua adalah guru. Guru adalah salah satu faktor utama dan tidak dapat digantikan oleh apapun dalam dunia pendidikan. Walaupun gedung sekolah/maddrasah dibangun dengan megah, fasilitas buku perpustakaan lengkap dan sarana pendidikan lainnya lengkap, mustahil kalau tidak ada guru akan terjadi proses belajar mengajar. Dalam artikel ini akan menguraikan dan menemukan faktor-faktor apa yang memicu rendahnya mutu pendidikan khususnya di Madrasah Aliyah berbasis kinerja guru.

\section{KAJIAN TEORITIS}

Input pendidikanadalah segala sesuatu yang harus tersedia karenadibutuhkan untuk berlangsungnya proses. Sesuatu yang dimaksud berupa sumberdaya dan perangkat lunak serta harapan-harapan sebagai pemandu bagi berlangsunnya proses. Input sumber daya meliputi sumberdaya manusia (kepala madrasah, guru termasuk guru BP/BK, karyawan, siswa) dan sumberdaya selebihnya (peralatan, perlengkapan, uang, bahan, dan lain-lain.). Inputpendidikan berupa perangkat lunak meliputi

$$
\text { Volume VII, Nomor 2, Juli - Desember } 2015 \mid 161
$$


struktur organisasi madrasah, peraturan perundang-undangan, deskripsi tugas, rencana, program, dan sebagainya. Input dapat berupa berupa visi, misi, tujuan, dan sasaran- sasaran yang ingin dicapai oleh madrasah. Kesiapan input sangat diperlukan agar proses dapat berlangsung dengan baik. Oleh karena itu, tinggi rendahnya mutu input dapat diukur dari tingkat kesiapan input. Makin tinggi tingkat kesiapan input, makin tinggi pula mutu input tersebut (Wheelen and Hunger, 1995).

Dalam pendidikan bersekala mikro (ditingkat madrasah), proses yang dimaksud adalah proses pengambilan keputusan, proses pengelolaan kelembagaan, proses pengelolaan program, proses belajar mengajar, dan proses monitoring dan evaluasi, dengan catatan bahwa proses belajar memiliki tingkat kepentingan tertinggi dibanding dengan proses- proses lainnya.

Proses dikatakan bermutu tinggi apabila pengkoordinasian dan penyerasian serta pemaduan input madrasah (guru, siswa, kurikulum, uang, peralatan dsb) dilakukan secara harmonis, sehingganya mampu menciptakan situasi pembelajaran yang menyenangkan (enjoyable learning), mampu mendorong motivasi dan minat belajar, dan benar-benar mampu memberdayakan peserta didik. Kata memberdayakan mengandung arti bahwa peserta didik tidak sekadar menguasai pengetahuan yang diajarkan oleh gurunya, akan tetapi pengetahuan tersebut juga telah menjadi muatan nurani peserta didik, dihayati, diamalkan dalam kehidupan sehari-hari dan lebih penting lagi peserta didik tersebut mampu belajar secara terus menerus (mampu mengembangkan dirinya). Output pendidikanadalah merupakan kinerja madrasah. Kinerja madrasah adalah prestasi madrasah yang dihasilkan dari proses/perilaku madrasah. Kinerja madrasah dapat diukur dari kualitasnya, efektivitasnya, produktivitasnya, efesiendinya, inovasinya, kualitas kehidupan kerjanya dan moral kerjanya. Khusus yang berkaitan dengan mutu output madrasah, dapat dijelaskan bahwa output madrasah dikatakan berkualitas/bermutu tinggi jika prestasi madrasah, khusunya prestasi belajar siswa, menunjukkan pencapaian yang tinggi dalam prestasi akademik, berupa nilai Ujian Nasional, karya ilmiah, lomba akademik, dan prestasi non-akademik, seperti

162 BIOTA: Jurnal Tadris IPA Biologi FITK IAIN Mataram 
IMTAQ, kejujuran, kesopanan, olah raga, kesenian, keterampilan kejujuran, dan kegiatan-kegiatan ektsrakurikuler lainnya.

Dikaitkan dengan pembelajaran bahwa pemikiran tentang bentuk kualitas dalam pembelajaran yang penting bahwa kualitas selalu terkait dengan kepuasan konsumen atau pelanggan dalam hal ini pelanggan utama adalah mahasiswa. Dari beberapa pernyataan tersebut dapat disimpulkan bahwa mutu adalah karakteristik dari suatu produk atau pelayanan yang sesuai dengan harapan dan kebutuhan pelanggan sehingga pelangggan merasa puas (Ellis R, 1995).

Sementara itu dari sudut perspektif TQM (Total Quality Management), mutu atau kualitas dipandang lebih luas. Mutu tidak hanya sekedar menekankan kepada aspek hasil saja, namun juga meliputi aspek proses, lingkungan, dan manusia. Hal ini jelas dalam definisi yang dirumuskan oleh Goestsch dan Davis bahwa kualitas merupakan suatu kondisi dinamis yang berhubungan dengan produk, jasa, manusia, proses, dan lingkungan yang memenuhi atau melebihi harapan (Edward S, 1993).

Menurut S. Murgatroyd, Steppen dan Collin Morgan (1994), implementasi manajemen mutu (TQM) yang sukses di lembaga pendidikan didasarkan pada lima kata kunci: visi (vision), strategi dan tujuan (strategy and goals), team (teams) dan alat (tools) serta Three Cs of TQM (3Cs.), yaitu budaya (culture), komitmen (commitment), dan komunikasi (communication).Dalam memberikan definisi mutu, menurut Edward S (1993) perlu dipahami perbedaan antara 3 (tiga) macam terminologi yang berkaitan dengan mutu, yakni pengawasan mutu (quality control), jaminan mutu (quality asurance) dan mutu total (total quality).Pengawasan mutu adalah mendeteksi dan menghapus komponen atau produk akhir yang tida mencapai standar. Pemeriksaaan dan pengujian adalah metode yang biasanya digunakan dalam pengawasan mutu, termasuk dalam dunia pendidikaan. Sedangkan jaminan mutu adalah melakukan cek sebelum dan selama proses berlangsung, agar kesalahan dapat dicegah lebih awal. Jaminan mutu adalah merancang mutu untuk memastikan bahwa produk yang dihasilkan sesuai dengan spesifikasi yang telah ditentukan. Philip B. Crosby menyebutkan

$$
\text { Volume VII, Nomor 2, Juli - Desember } 2015 \mid 163
$$


dengan istilah zero efects. Sedangkan total qualityadalahmenciptaka budaya mutu yang dapat menyenangkan pelangan dan membentuk struktur organisasi dalam penerapannya.

Mutu pendidikan menurut Murgatroyd, Stephen dan Collin Morgan, (1994) dapat dikategorikan menjadi 4(empat) macam, yaitu :

a. Mutu input, yaitu yang meliputi mutu SDM dan non SDM

b. Mutu proses, yang meliputi proses pengambilan keputusan, proses pengelolaan kelembagaan, proses pengelolaan program, proses belajar mengajar, proses monitoring dan proses evaluasi.

c. Mutu output pendidikan, yaitu prestasi kelulusan suatu pendidikan dengan indikator nilai yang tinggi.

d. Mutu outcame, yaitu jumlah kelulusan dengan pekerjaan yang ditekuni sesuai dengan jurusan dan keahlian yang dimiliki oleh lulusan pendidikan tersebut.Mutu dalam konteks "hasil pendidikan" mengacu pada prestasi yang dicapai oleh madrasah pada setiap kurun waktu tertentu (apakah tiap akhir cawu, akhir tahun, 2 tahun atau 5 tahun, bahkan 10 tahun). Prestasi yang dicapai atau hasil pendidikan (student achievement) dapat berupa hasil test kemampuan akademis (misalnya ulangan umum, Ebta atau Ebtanas). Dapat pula prestasi di bidang lain seperti prestasi di suatu cabang olah raga, seni atau keterampilan tambahan tertentu misalnya : komputer, beragam jenis teknik, jasa. Prestasi madrasah juga dapat berupa kondisi yang tidak dapat dipegang (intangible) seperti suasana disiplin, keakraban, saling menghormati, kebersihan, dan sebagainya. Antara proses dan hasil pendidikan yang bermutu saling berhubungan. Agar proses yang baik itu tidak salah arah, maka mutu dalam artian hasil (ouput) harus dirumuskan lebih dahulu oleh madrasah, dan harus jelas target yang akan dicapai untuk setiap tahun atau kurun waktu lainnya. Berbagai input dan proses harus selalu mengacu pada mutu-hasil (output) yang ingin dicapai. 
Pengertian mutu memiliki variasi, produsen (penyedia barang/jasa) atau konsumen (pengguna/pemakai barang/jasa) akan memiliki definisi yang berbeda mengenai mutu barang/jasa. Perbedaan ini mengacu pada orientasi masing-masing pihak mengenai barang/jasa yang menjadi objeknya. Satu kata yang menjadi benang merah dalam konsep mutu baik menurut produsen dan konsumen adalah kepuasan. Barang/jasa yang dikatakan bermutu adalah yang dapat memberikan kepuasan baik bagi pelanggan maupun produsennya.

Pendidikan yang bermutu merupakan tuntutan masyarakat Indonesia sebagai wahana untuk menghasilkan sumber daya manusia bermutu yang mampu bersaing secara global. Upaya mewujudkan pendidikan yang bermutu memerlukan strategi, langkah-langkah kongkret dan operasional yang dilakukan secara berkelanjutan.

Salah satu langkah kongkret peningkatan mutu pendidikan adalah pemberdayaan satuan pendidikan agar mampu berperan sebagai subyek penyelenggara pendidikan, yang diberi kewenangan dan peran luas untuk merancang serta melaksanakan pendidikan sesuai dengan potensi dan kondisi masing-masing, dengan tetap mengacu pada Standar Nasional Pendidikan (SNP).

Terdapat dua faktor yang dapat menjelaskan mengapa upaya perbaikan mutu pendidikan selama ini kurang atau tidak berhasil. Faktor pertama adalah strategi pembangunan pendidikan yang selama ini lebih bersifat input oriented. Strategi yang demikian lebih bersandar kepada asumsi bahwa bilamana semua input pendidikan telah dipenuhi, seperti penyediaan bukubuku (materi ajar) dan alat belajar lainnya, penyediaan sarana pendidikan, pelatihan guru dan tenaga kependidikan lainnya, maka secara otomatis lembaga pendidikan (madrasah) akan dapat menghasilkan output (keluaran) yang bermutu sebagaimana yang diharapkan.

Ternyata strategi ini tidak berfungsi sepenuhnya di lembaga pendidikan (madrasah), melainkan hanya terjadi dalam institusi ekonomi dan industri. Faktor kedua adalah pengelolaan 
pendidikan yang lebih bersifat macro-oriented, diatur oleh jajaran birokrasi di tingkat pusat. Akibatnya, banyak faktor yang diproyeksikan di tingkat makro (pusat) tidak terjadi atau tidak berjalan sebagaimana mestinya di tingkat mikro (madrasah). Dengan singkat dapat dikatakan bahwa kompleksitasnya cakupan permasalahan pendidikan seringkali tidak dapat terpikirkan secara utuh dan akurat oleh birokrasi pusat.

Ara Hidayat dan Imam Machali (2010), mengemukakan bahwa manajemen mutu dalam pelaaksanaan program pendidikan bukanlah tujuan tetapi alat atau metode untuk mencapai mutu dan meningkakan performance yang diharapkan. Banyak cara atau upaya yang dapat dilakukan untuk meningkatkan mutu diantaranya menggunakan standar-standar sistem manajemen yang telah dirumuskan oleh lembaga-lembaga penjamin mutu. Sistem manajemen yang telah ada seperti international standardization of organisation (ISO), six sigma, malcolm baldrige, singapure quality award, standar nasional indonesia dan indonesian plywood standard.

Penurunan mutu pendidikan yang disebabkan oleh faktorfaktor: (1) masih kukuhnya pengaruh faham behaviorisme dalam sistem pendidikan kita, (2)kapasitas mayoritas pendidik kita dalam mengangkat struktur dasar bahan ajar masih relatif rendah, (3) tuntutan zaman yang makin pragmatis, dan (4) terdapat sikap dan pendirian yang kurang menguntungkan bagi tegaknya demokrasi pendidikan" (Deddy Mulyana, 2004).

Aspek-aspek yang menyebabkan mutu pendidikan tidak mengalami peningkatan secara merata, diantaranya; 1) kebijakan dan penyelenggaraan pendidikan nasional menggunakan pendekatan education production function atau input-output analysis yang tidak dilaksanakan secara konsekuen; 2) penyelenggaraan pendidikan nasional dilakukan secara birokratiksentralistik, sehingga menempatkan madrasah sebagai penyelenggara pendidikan sangat tergantung pada keputusan birokrasi. Madrasah lebih merupakan subordinat dari birokrasi di atasnya, sehingga mereka kehilangan kemandiriannya, keluwesan, motivasi, kreatifitas /inisiatif untuk mengembangkan dan memajukan lembaganya; dan 3) partisipasi dan peranserta warga

166 BIOTA: Jurnal Tadris IPA Biologi FITK IAIN Mataram 
madrasah khususnya guru seringkali diabaikan dalam pengambilan keputusan, dan peranserta masyarakat khususnya.

Menurut Hoy, Wayne Miskel (2008), sekolah bermutu adalah sekolah yang efektif, yang terdiri dari tatanan masukan (input), proses (process) dan keluaran (out-put).Dengan demikian, madrasah bermutu adalah madrasah yang menerapkan rumusan sekolah efektif. Secara out-put, hasil yang diperoleh dari madrasah efektif adalah: pertama, dari aspek siswa, lulusan yang dihasilkan adalah siswa yang memiliki prestasi akademik yang unggul, memiliki kreativitas, percaya diri, aspiratif, tidak ragu mengemukakan pendapat, memiliki ekspekatasi yang tinggi, selalu hadir dalam kegiatan dan memiliki tingkat keulusan yang tinggi dan sebaliknya angka putus sekolah tidak ada sama sekali atau nol persen.

J Sudarminta (2009) mengatakan, dari sisi guru sendiri rendahnya mutu guru tampak dari gejala: 1) lemahnya penguasaan bahan yang diajarkan; 2) ketidaksesuaian antara bidang studi yang dipelajari guru dan yang dalam kenyataan di lapangan dijabarkan; 3) kurang efektifnya cara pengajaran; 4) kurangnya wibawa guru di hadapan murid; 5) lemahnya motivasi dan dedikasi untuk menjadi pendidik yang sungguh-sungguh; semakin banyak yang kebetulan menjadi guru dan tidak betulbetul menjadi guru; 6) kurangnya kematangan emosional, kemandirian berpikir, dan keteguhan sikap sehingga dari kepribadian mereka sebenarnya tidak siap sebagai pendidik dan 7) relatif rendahnya kapasitas intelektual calon guru dan para guru.

Dari aspek guru, sekolah yang bermutu memperhatikan kepuasan kerja guru, agka absen nol persen dan memberikan amanah kepada guru untuk tugas-tugas tertentu. Komariah dan Triatna mengemukakan bahwa guru merupakaan ujung tombak pendidikan. Dimana keberadaan guru menjadi aspek yang sangat penting bagi keberhasilam sekolah, terutama bagi guru yang melaksanakan fungsi mengajarnya dengan penuh makna (purposeful teaching) (Aan Komariah dan Ce[pi Triana, 2006). 


\section{ANALISIS KRITIS}

Terdapat 3 (tiga) faktor yang dapat diidentifikasi yang menyebabkan rendahnya mutu pendidikan diantaranya adalah:

1. Kebijakan dan penyelenggaraan pendidikan nasional menggunakan pendekatan education function atau inputoutput analysis yang tidak dilaksanakan secara konsekuen. Dengan pendekatan ini fungsi lembaga pendidikan dilihat sebagai pusa produksi yang apabila semua keutuhan input dipenuhi sebagai output yang diharapkan akan meningkat pula. Murid diperlakukan row input semntara guru, kurikulum dan fasilitas diperlukan sebagai instrumental input. Dalam pendekatan ini pemenuhan segala kebutuhan input sepertipelatihan guru, pengadaan buku dan alat pelajaran, perbaikan sarana dan prasarana lebih ditekankan tanpa melihat proses sebagai bagian dari sebuah kegiatan pendidikan yang lebih penting.

2. Penyelenggaraan pendidikan nasional diselenggarakan secara sentralistik yang menempatkan madrasah sebagai penyelenggara pendidikan. Sebagai pelaksana yang sangat tergantung pada keputusan yang diambil pada tingkat pusat yang kadang-kadang tidak sesuai dengan kondisi yang dihadapi madrasah pada tataran realistisnya. Dengan demikian madrasah kehilangan kemandirian, motivasi, kreativitas, inovasi dan daya imajinasi serta inisiaifnya untuk mengelola dan menyelesaikan masalah yang dihadapinya. Dalam hal peningkatan mutu pendidikan madrasah tidak memiliki kelesluasan berbuat, kewenangan penentukan program dan kegiatan-kegiatan lainnya yang diharapkan mampu meningkatkan mutu output pendidikan yang dihasilkan.

3. Peran serta masyarakat, terutama orang tuaa siswa dalam penyelenggaraan pendidikan selama ini sangat minim. Hal ini muncul karena madrasah dipandang sebagai sebuah perusahaan industri yang melayani kebutuhan individu. Dengan pandangan demikian, madrasah lebih bersifat frahmented dan menganggap madrasah sebagai lembaga yang berdiri sendiri dan terpisah dari masyarakat sekitarnya.

168 BIOTA: Jurnal Tadris IPA Biologi FITK IAIN Mataram 
Partisipasi masyarakat yang selama ini terjadi lebih banyak pada dukungan input dana tanpa memperhatikan proses seperti: pengambilan keputusan, monitoring, evaluasi dan akuntabilitas. Dalam keadaan seperti ini madrasah menjadi tidak memiliki beban untuk mempertangung jawabkan program-program yang dilakukannya. Mestinya seluruh masyarakat sebagai salah satu pihak yang berkepentingan steakholderharus kut mengontrol apa yang terjadi di madrasah.

Faktor-faktor yang mempengaruhi mutu pendidikan adalah faktor internal dan faktor eksternal. Adapun faktor internal berupa kurikulum, sumberdaya ketenagaan, sarana dan prasarana, pembiayaan pendiddikan, manajemen madrasah dan kepemimpinan. Sedangkan faktor eksternal adalah partisipasi politik rendah, ekonomi yang tidak berpihak pada pendidikan, sosial budaya yang tidak mendukung serta rendahnya pemanfaatan sains dan teknologi.

Penyelenggaraan pendidikan yang berkualitas didasarkan pada empat ukuran atau indikator, yaitu (1) mutu produk atau lulusan, (2) mutu proses pembelajaran, (3) mutu layanan sekolah dan (4) mutu lingkungan sekolah.

1. Mutu produk atau lulusan pendidikan dapat dinilai berdasarakan nilai ujian akhir nasional atau sekolah yang tinggi. Tetapi tentunya nilai bukan satu-satunya ukuran, harus didukung dengan ukuran lainnya yaitu lulusan lembaga pendidikan juga mempunyai kecakapan dan ketrampilan untuk hidup (life skills), yang dapat dimanfaaatkan untuk bekal hidup peserta didik di masyarakat. Selain itu tentunya lulusan pendidikan juga mempunyai nilai-nilai kemanusian yang tinggi, yang responsi terhadap persoalan sosial yang ada.

2. Mutu proses pembelajaran sangat ditentukan pada profesionalisme guru. Guru dalam pembelajaran tidak hanya mengajarkan ilmu pengetahuan semata tetapi juga mendidik, mengarahkan dan menggerakan siswa agar menjadi manusia seutuhnya, tidak hanya pandai dan terampil tetapi juga berintegritas serta berbudi pekerti yang luhur. 
3. Mutu layanan sekolah yang baik tidak hanya layanan kepada siswa akan tetapi kepada orang tua, tamu sekolah dan lain sebagainya. Mutu layanan juga ditentukan dari kemampuan pelaku sekolah untuk dapat menjalin hubungan dan memberikan pelayanan yang terbaik pada suluruh stakeholder sekolah.

4. Mutu lingkungan sekolah ditunjukkan dengan sekolah yang bersih, indah, damai. Dengan lingkungan yang baik akan menciptakan kenyamanan proses belajar mengajar di sekolah.

Pemerintah maupun masyarakat berupaya untuk melakukan pendidikan dengan standar kualitas yang diinginkan untuk memberdayakan manusia. "Sistem pendidikan yang dibangun harus disesuaikan dengan tuntutan zamannya, agar pendidikan dapat menghasilkan outcome yang relevan dengan tuntutan zaman. Dari sini, pendidikan dipandang sebagai katalisator yang dapat menunjang faktor-faktor lain. Artinya, pendidikan sebagai upaya pengembangan sumber daya manusia (SDM) menjadi semakin penting dalam pembangunan suatu bangsa.

\section{PENUTUP}

\section{Kesimpulan}

Berdasarkan uraian pembahasan dapat disimpulkan :

1. Penyelenggaraan pendidikan nasional diselenggarakan secara sentralistik yang menempatkan madrasah sebagai penyelenggara pendidikan. Sebagai pelaksana yang sangat tergantung pada keputusan yang diambil pada tingkat pusat yang kadang-kadang tidak sesuai dengan kondisi yang dihadapi madrasah pada tataran realistisnya. Dengan demikian madrasah kehilangan kemandirian, motivasi, kreativitas, inovasi dan daya imajinasi serta inisiaifnya untuk mengelola dan menyelesaikan masalah yang dihadapinya.

2. Peran serta masyarakat, terutama orang tuaa siswa dalam penyelenggaraan pendidikan selama ini sangat minim. Hal ini muncul karena madrasah dipandang sebagai sebuah

170 BIOTA: Jurnal Tadris IPA Biologi FITK IAIN Mataram 
perusahaan industri yang melayani kebutuhan individu. Dengan pandangan demikian, madrasah lebih bersifat frahmented dan menganggap madrasah sebagai lembaga yang berdiri sendiri dan terpisah dari masyarakat sekitarnya. Partisipasi masyarakat yang selama ini terjadi lebih banyak pada dukungan input dana tanpa memperhatikan proses seperti: pengambilan keputusan, monitoring, evaluasi dan akuntabilitas.

\section{DAFTAR PUSTAKA}

Anonim, Kapita Selekta Akreditasi, Badan Akreditasi Nasional Sekolah/Madrasah, Jakarta, 2015

Anonim, Mekanisme Prosedur Operasional Standar Akreditasi, Badan Akreditasi Nasional Sekolah/Madrasah, Jakarta, 2015

Anonim, Peran Akreditasi dalam Penjaminan Mutu, Badan Akreditasi Nasional Sekolah/Madrasah, Jakarta, 2015

Edward, Sallis. Total Quality Management in Education, Manajemen Mutu Pendidikan. Yogyakarta: Grasida, 2008

Engkoswara dan Aan Komariah, Administrasi Pendidikan, Yogyakarta: Andi Offset, 2010

Hidayat, Ara dan Machali, Imam., Pengelolaan Pendidikan, Bandung: Pustaka Educe, 2010

Jalal, Fasli dan Supriyadi, Dedi (ed), Reformasi Pendidikan Nasional dalam Konteks Otonomi Daerah, Yogyakarta: Adicita Karya Nusa, 2001

Joel E, Ross,. Total Qulity Management; Text, Cases and Readings. USA:St Lucie Press. 1993

Mulyana, Deddy. Metodologi Penelitian Kualitatif, Paradigma Baru Ilmu Komunikasi dan Ilmu Sosial Lainnya, Bandung; PT Remaja Rodakarya. 2004

Murgatroyd, Stephen dan Morgan, Colin. Total Quality Management and The School. Buckingham;Open University Press.1994 
Palmer Joy A, Fifty Major Thinkerson Education, London and New York: Routledge, 2001

R. Ellis,. Quality Assurance for University Teaching, Bristol USA: Open University,1995

Suyanto dan M.S. Abbas, Wajah dan Dinamika Pendidikan Anak Bangsa, Yogyakarta: Adicita Karya Nusa, 2001

Syafaruddin, Manajemen Mutu Terpadu dalam Pendidikan, Jakarta: PT. Grasindo, 2002

Wheelen-Hunger. Strategic Management and Bussines Policy. Fifrth Edition.New York:Addison-Wesley Publishing Company,1995

172 BIOTA: Jurnal Tadris IPA Biologi FITK IAIN Mataram 